\title{
The Influence of Corporate Social Responsibility on the Attractiveness of Employers in the Perception of Generation Z
}

\author{
Jolanta Maj iD \\ Opole University of Technology \\ Natalia Kasperek \\ Opole University of Technology
}

\section{Introduction}

Research indicates that although corporate social responsibility (CSR) is gaining significance as a communication and employer-branding tool ${ }^{1}$, little attention has been paid to the effect of corporate social performance and ethical issues on recruitment ${ }^{2}$. Klimkiewicz and Oltra have analysed whether a company's CSR image can influence the perception of the attractiveness of employers for Generation $\mathrm{Y}^{3}$. They came to the conclusion that the respondent's personal perception of the concept of CSR plays a key role in understanding CSR signals and, therefore, influences the perception of the attractiveness of an employer. As their study focused on Generation Y, which has already been present on the labour market for several years, we decided to verify the results in relation to Generation $Z$, which is currently entering the labour market. The differences between particular generations require various approaches

1 M.X. Amaladoss, H.L. Manohar, Communicating Corporate Social Responsibility - A Case of CSR Communication in Emerging Economies, "Corporate Social Responsibility and Environmental Management" 2013, no. 20, issue 2, pp. 65-80.

2 See: K.B. Backhaus, An Exploration of Corporate Recruitment Description on Monster.com, "Journal of Business Communication" 2004, no. 41, issue 2, pp. 115-136; K.B. Backhaus, B.A. Stone, K. Heiner, Exploring the Relationship Between Corporate Social Performance and Employer Attractiveness, "Business \& Society" 2002, no. 41, issue 3, p. 292.

3 K. Klimkiewicz, V. Oltra, Does CSR Enhance Employer Attractiveness? The Role of Millennial Job Seekers' Attitudes, "Corporate Social Responsibility and Environmental Management" 2017, no. 24, issue 5, pp. 449-463. 
to be used, as well as sensibility in regards to understanding their needs and values 4 . Although Generations $Y$ and $Z$ share a number of characteristics, there are also crucial differences; such as the higher mobility of Generation $\mathrm{Z}$ or a greater flexibility when switching from the real to the virtual world ${ }^{5}$, all of which justifies the necessity of a separate analysis. Due to these differences in the value system and the hierarchy of needs between particular generations, a novel approach may be required from organisations in terms of their branding and to attract new employees. With this in mind, the main goal of the paper is to analyse the influence of Generation Z's perception of CSR in terms of the perceived CSR-based attractiveness of employers. For this purpose, we conducted a survey.

The paper is organised in the following way. First the results of a literature review in regard to CSR as a factor influencing the attractiveness of employers are presented. Then the characteristics of Generation $\mathrm{Z}$ are outlined, followed by the description of the research design, methodology as well as the research sample. Finally, the research results are presented, followed by a conclusion and an implications section.

\section{Corporate Social Responsibility and Employer Attractiveness}

The systemic literature review revealed an existing, positive link between CSR and the reputation of an organisation ${ }^{6}$. Studies support the idea that responsible organisations are more attractive to job seekers than non-ethical firms or organisations with a bad reputation. However, social integration factors (like prior awareness of CSR or cooperation with NGOs) have a greater influence on the assessment of CSR than personal traits and factors7. These attitudes towards CSR influence job

4 M. Bednarska, A. Grobelna, Zmiana pokoleniowa na rynku pracy w turystyce, "Studia Oeconomica Posnaniensia" 2017, no. 5, issue 4, pp. 104-125.

5 A. Dolot, Proces poszukiwania pracy przez młode pokolenie - wybrane zagadnienia - wyniki badań empirycznych, "Studia Ekonomiczne" 2018, no. 359, pp. 284-299.

6 See: T.S. Behrend, B.A. Baker, L.F. Thompson, Effects of Pro-Environmental Recruiting Messages: The Role of Organizational Reputation, "Journal of Business and Psychology" 2009, no. 24, issue 3, pp. 341-350; C. Maden et al., Linking corporate social responsibility to corporate reputation: a study on understanding behavioral consequences, [in:] Proceedings of the 8th International Strategic Management Conference, 2012, no. 58, pp. 655-664; T. Melo, A. Garrido-Morgado, Corporate Reputation: A Combination of Social Responsibility and Industry, "Corporate Social Responsibility and Environmental Management" 2012, no. 19, issue 1, pp. 11-31.

7 J. Barrena-Martinez et al., Corporate Social Responsibility in the Process of Attracting College Graduates, "Corporate Social Responsibility and Environmental Management" 2015, 
seekers' perception of an organisation's CSR actions and associated communication, and thus CSR-based employer attractiveness ${ }^{8}$, which is why an individual's attitudes towards CSR were chosen as an independent variable for the study.

These attitudes consist of three elements: cognitive, affective and behavioural ${ }^{9}$. The cognitive dimension of the attitude towards CSR includes perception of an organisation's CSR commitment ${ }^{10}$. Basu and Palazzo distinguished two types of commitment: instrumental and normative. Instrumental commitment is externally driven and results from the "business case" for CSR, e.g., the potential profits CSR may bring. The roots of normative commitment are ethical and result from an attempt to meet social values and satisfy social standards and norms ${ }^{11}$. The affective dimension refers to the individual's assessment of an organisation's CSR characteristics, and the behavioural dimension represents the individual's interest in CSR or business ethics ${ }^{12}$, as well as the willingness to deepen one's knowledge about CSR issues or undertake volunteering activities ${ }^{13}$.

As Klimkiewicz and Otra discovered, attitudes towards CSR influence the perceived CSR-based attractiveness of an employer by Generation Y. CSR-based employer attractiveness was higher for respondents perceiving CSR in normative terms (rather than instrumental), for respondents positively assessing CSR, as well as for those showing CSR engagement ${ }^{14}$. However, as their research focused on Generation Y, we believe that, due to differences between generations, it is necessary to verify those results in relation to Generation $Z$. Thus, the following hypotheses were formulated: $\mathrm{H1}$ : Representatives of Generation $\mathrm{Z}$ who perceive CSR in a normative way will show higher CSR-based employer attractiveness than those who perceive CSR in an instrumental way.

H2: Representatives of Generation Z who assess CSR positively will show higher CSR-based employer attractiveness than those who assess CSR negatively.

no. 22, issue 6, pp. 408-423.

8 K. Klimkiewicz, V. Oltra, Does CSR Enhance Employer Attractiveness?...

9 E. Aronson, T.D. Wilson, R.M. Akert, Social psychology, Prentice Hall/Pearson Education, New Jersey 2002.

10 K. Klimkiewicz, V. Oltra, Does CSR Enhance Employer Attractiveness?...

11 K. Basu, G. Palazzo, Corporate social responsibility: A process model of sensemaking, "Academy of Management Review" 2008, no. 33, issue 1, p. 125.

12 W.R. Evans, W.D. Davis, An Examination of Perceived Corporate Citizenship, Job Applicant Attraction, and CSR Work Role Definition, "Business \& Society" 2011, no. 50, issue 3, pp. 456-480.

13 A. Perez, I.R. del Bosque, Corporate social responsibility and customer loyalty: exploring the role of identification, satisfaction and type of company, "Journal of Services Marketing" 2015, no. 29 , issue 1 , pp. 15-25.

14 K. Klimkiewicz, V. Oltra, Does CSR Enhance Employer Attractiveness?... 
H3: Representatives of Generation $\mathrm{Z}$ who show a higher CSR engagement will show higher CSR-based employer attractiveness than those with low CSR engagement.

\section{Generation Z}

The literature identifies as least five different generations in the modern world: the traditionalists (born between 1928 and 1944), baby boomers (born between 1945 and 1965), Generation X (born between 1965 and 1979), the previously mentioned Generation Y (born between 1980 and 1995) and Generation Z (born after 1995$)^{15}$. However, as noted inter alia by Dolot ${ }^{16}$ not only does the literature presents differences in defining the age range characteristic for Generation Z, but there is also no consensus as to the naming of this generation. They are also called the "C - Generation"17, "iGeneration"18, "Facebook generation", "D - Digital - Generation"19 or "R - Responsibility - Generation" 20.

The literature notes different strengths and weaknesses of this generation. Among factors important for Generation Z, Dolot highlights giving and expecting feedback, the perception of the communication process as bidirectional ${ }^{21}$. This generation can be described through its natural ability to use and ease of using new technologies, high mobility, self-perception as well-organised, and social conscientiousness both when job-seeking and while in employment. Mazurek-Łopacińska indicates their strong desire to express themselves and share opinions ${ }^{22}$. What

15 E.J. Cilliers, The challenge of teaching generation Z, "PEOPLE: International Journal of Social Sciences" 2017, no. 3, issue 1, pp. 188-198.

16 A. Dolot, Co motywuje do pracy pokolenie Z - wybrane zagadnienia - wyniki badań empirycznych, "Przedsiębiorczość i Zarządzanie" 2018, no. 19, issue 8, pp. 227-242; A. Dolot, The characteristics of Generation Z, "E-mentor" 2018, no. 74, issue 2, pp. 44-50.

17 J. Wiktorowicz, I. Warwas, Pokolenia na rynku pracy, [in:] J. Wiktorowicz et al. (eds), Pokolenia - co się zmienia? Kompendium zarzq̨dzania multigeneracyjnego, Wolters Kluwer, Warszawa 2016, pp. 19-37.

18 T.L. Austin, L.C. Clark, L.S. Sigmar, Practical Persuasive Communication: The Evolving Attitudes of the iGeneration Student, "e-Journal of Business Education and Scholarship of Teaching" 2018, no. 12, issue 3, pp. 14-33.

19 L. Mladkova, Generation Z in the Literature, [in:] Proceedings of the 14th International Conference Efficiency and Responsibility in Education, Czech University of Life Sciences, Prague 2017, pp. 255-261.

20 Z.E. Csobanka, The $Z$ generation, "Acta Technologica Dubnicae" 2016, no. 6, issue 2, pp. 63-76.

21 A. Dolot, The characteristics...

22 K. Mazurek-Łopacińska, Generacja Z - cele, wartości życiowe i wyzwania dla współczesnych przedsiębiorstw, "Konsumpcja i Rozwój” 2018, no. 160, issue 4, pp. 62-75. 
is more, their workplace behaviour differs from older employees, as, for example, trust and respect of superiors is not automatic and needs to be earned through professional excellence ${ }^{23}$. They have a stronger preference towards individual work than Generation $\mathrm{Y}$ and also face difficulties adapting to imposed working conditions and time organisation, and they expect to be delegated ambitious tasks ${ }^{24}$.

Among their strengths, Ratajczak points to openness, tolerance, independence, high self-esteem and the desire to develop ${ }^{25}$. Wiktorowicz and Warwas also mention their high level of creativity and innovativeness, as well as tolerance for risk. They perceive diversity as natural ${ }^{26}$. Among their weaknesses, Ratajczak mentions impatience, difficulties with face-to-face communication, immaturity, overestimation of own skills and the lack of ability to tolerate criticism ${ }^{27}$. Wiktorowicz and Warwas add the lack of willingness to become independent, putting too much trust in information found online, the desire and need to have everything "just in time". From their employers they demand respect, a good organisational climate, development opportunities, fair pay and other non-financial motivators ${ }^{28}$. It should also be noted that Generation $\mathrm{Z}$ is perceived as highly divided due to cultural and economic factors ${ }^{29}$.

\section{Research design and methodology}

The research was conducted based on the research design proposed by Klimkiewicz and Oltra. In order to compare our obtained results with theirs, we employed the research tool provided by the authors ${ }^{30}$. The original questionnaire was translated into Polish and verified in a pilot study. Similarly, we used three independent variables assessing the cognitive dimension: CSR perception (normative and instrumental), affective dimension: CSR assessment and behavioural dimension: CSR engagement. The dependent variable: CSR-based employer attractiveness was

23 K. Lazányi, Y. Bilan, Generation Z on the Labour Market - Do They Trust Others Within Their Workplace?, "Polish Journal of Management Studies" 2017, no. 16, issue 1, pp. 78-93.

24 J. Gajda, Analiza wybranych aspektów oczekiwań zawodowych przedstawicieli pokoleń Y i Z, "Zarządzanie Zasobami Ludzkimi" 2019, no. 5, issue 130, pp. 93-112.

25 J. Ratajczak, Pozyskiwanie $i$ utrzymanie w organizacji pracowników z pokolenia Z w kontekście ich oczekiwań względem pracy, "Prace Naukowe Uniwersytetu Ekonomicznego we Wrocławiu” 2018, no. 512, pp. 206-215.

26 J. Wiktorowicz, I. Warwas, Pokolenia na rynku...

27 J. Ratajczak, Pozyskiwanie i utrzymanie w organizacji pracowników...

28 J. Wiktorowicz, I. Warwas, Pokolenia na rynku...

29 A. Żarczyńska-Dobiesz, B. Chomątowska, Pokolenie "Z" na rynku pracy - wyzwania dla zarzqdzania zasobami ludzkimi, "Prace Naukowe Uniwersytetu Ekonomicznego we Wrocławiu" 2014, no. 350, pp. 405-415.

30 K. Klimkiewicz, V. Oltra, Does CSR Enhance Employer Attractiveness?..., pp. 454-455. 
measured using the importance of CSR in looking for a job and the tendency to reject a job offer from an employer which is not perceived as socially responsible.

The sample included 250 respondents representing Generation Z. The structure of the sample is presented in Table 1.

Table 1. Structure of the sample

\begin{tabular}{|c|l|r|}
\hline \multirow{3}{*}{ Gender } & Female & $54.4 \%$ \\
\cline { 2 - 3 } & Male & $45.6 \%$ \\
\hline \multirow{4}{*}{ Professional experience } & None & $51.6 \%$ \\
\cline { 2 - 3 } & Up to 12 months & $27.6 \%$ \\
\cline { 2 - 3 } & From 1 to 2 years & $8.0 \%$ \\
\cline { 2 - 3 } & More than 3 years & $12.8 \%$ \\
\hline \multirow{2}{*}{ Cycle of studies } & First-cycle studies & $87.6 \%$ \\
\cline { 2 - 3 } & Second-cycle studies & $12.4 \%$ \\
\hline \multirow{3}{*}{ Study major } & Economics & $31.2 \%$ \\
\cline { 2 - 3 } & Management & $24.4 \%$ \\
\cline { 2 - 3 } & Mechanical engineering & $10.8 \%$ \\
\cline { 2 - 3 } & Informatics & $10.4 \%$ \\
\cline { 2 - 3 } & Automation and Robotics & $6.8 \%$ \\
\cline { 2 - 3 } & Mechatronics & $5.2 \%$ \\
\cline { 2 - 3 } & Architecture & $6.4 \%$ \\
\cline { 2 - 3 } & Other & \\
\hline
\end{tabular}

Source: own elaboration.

The research was conducted using a PAPI (paper and pencil interview) as well as a CAWI (computer assisted, web-based interview) questionnaire. In total, 332 surveys were distributed of which 82 were not completed. The total sample included 250 surveys.

\section{Research results}

The hypotheses were tested using scales adopted from Klimkiewicz and Oltra ${ }^{31}$, which measured respondents' attitudes toward CSR, and included three independent variables CSRNormative, CSRPositiv and CSREnga. CSRNormative relates to the respondents CSR perception (normative or instrumental), CSRPositiv relates to the affective dimension: and CSREnga to CSR engagement. The dependent variable - perceived CSR-based employer attractiveness includes two dimensions (CSRImporance and NoCSRReject). In order to test the hypotheses, we conducted a linear regression analysis (Table 2 and Table 3 ). The analysis was conducted using R software.

31 Ibidem. 
Table 2. Multiple regression for the attitudes of individuals from Generation Z's towards CSR and CSR-based employer attractiveness (CSRImportance)

\begin{tabular}{|l|c|c|c|c|}
\cline { 2 - 5 } \multicolumn{1}{c|}{} & Estimate & Std. Error & t value & $\operatorname{Pr}(>|\mathrm{t}|)$ \\
\hline Intercept & 1.87431 & 0.39040 & 4.801 & $2.74 \mathrm{e}-06^{\star \star \star}$ \\
\hline CSRNormative & -0.24811 & 0.06022 & -4.120 & $5.18 \mathrm{e}-05^{\star \star \star}$ \\
\hline CSRPositive & 0.21346 & 0.08367 & 2.551 & $0.0113^{\star}$ \\
\hline CSREnga & 0.40706 & 0.05577 & 7.299 & $4.00 \mathrm{e}-12^{\star \star \star}$ \\
\hline
\end{tabular}

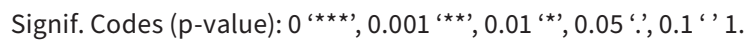
Residual standard error: 0.6044 on 246 degrees of freedom. Multiple R-squared: 0.3251, Adjusted R-squared: 0.3169. F-statistic: 39.5 on 3 and 246 DF, p-value: $<2.2 \mathrm{e}-16$.

Source: own elaboration.

Table 3. Multiple regression for the attitudes of individuals from Generation Z's towards CSR and CSR-based employer attractiveness (NoCSRReject)

\begin{tabular}{|l|r|c|c|c|}
\cline { 2 - 5 } \multicolumn{1}{c|}{} & Estimate & Std. Error & t value & $\operatorname{Pr}(>|\mathrm{t}|)$ \\
\hline Intercept & 2.53392 & 0.56374 & 4.495 & $1.07 \mathrm{e}-05^{\star \star *}$ \\
\hline CSRNormative & -0.21820 & 0.08696 & -2.509 & 0.0127 \\
\hline CSRPositive & 0.18645 & 0.12082 & 1.543 & 0.1241 \\
\hline CSREnga & 0.15331 & 0.08054 & 1.904 & 0.0581 \\
\hline
\end{tabular}

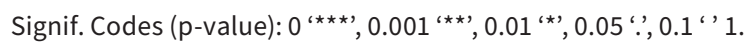
Residual standard error: 0.8728 on 246 degrees of freedom. Multiple R-squared: 0.07929, Adjusted R-squared: 0.06806. F-statistic: 7.062 on 3 and 246 DF, p-value: 0.0001427.

Source: own elaboration.

The conducted analysis demonstrates that the hypotheses were verified to a certain degree. A statistically significant relation between Generation Z's CSR perception (normative and instrumental) and the perceived CSR-based employer attractiveness was detected (H1), however, it seems that in relation to Generation $\mathrm{Z}$ the instrumental perception of CSR is more influential. In regards to the second and third hypotheses, in both cases the independent variables (CSRPositive and CSR Enga) influence only the CSR-based employer attractiveness dimensions related to the importance of CSR in looking for a job, while there is no statistically significant relation with the tendency to reject a job offer from an employer who is not perceived as socially responsible. Thus, the conclusion may be drawn that representatives of Generation Z perceive CSR as an important factor for their employer choice, though not so important as to convince them to reject a job offer if the employer is not perceived as ethical and responsible. 


\section{Discussion and conclusion}

The main goal of the paper was to verify whether the results obtained by Klimkiewicz and Oltra in relation to job seekers from Generation $Y$ also apply to Generation $\mathrm{Z}^{32}$. The conducted research shows that there are differences between those generations. Klimkiewicz and Oltra found that job seekers from Generation $\mathrm{Y}$ are more likely to reject a job offer from an unethical employer ${ }^{33}$, while in our study this relation was stronger for the normative-oriented respondents. Furthermore, we found statistically significant relations for the two other independent variables in relation to both dimensions of CSR-based employer attractiveness, and not only in regard to the importance of CSR in looking for a job. Comparing these two generations demonstrates that although CSR is important for both, Generation Y seems more concerned with the issues investigated. This generation not only perceives CSR-based employer attractiveness from a different, normative perspective, but also seems to be willing to "go further" when it comes to accepting posts in order to comply with CSR.

The conducted research has several theoretical and practical implications. Firstly, it provides further understanding of the role of attitudes towards CSR in CSRbased employer attractiveness by adding the perspective of Generation Z. Secondly, it shows that there are differences between Generations $\mathrm{Y}$ and $\mathrm{Z}$ (as well as older generations), which justifies a separate analysis. Apart from the differences between the Generations Y and Z, the results reveal that CSR plays an important role in the decision-making process of job seekers from both generations. It seems that this factor should not be downplayed by employers (especially in times of the "war for talent"), as it may play a crucial role when these generations are seeking employment or deciding whether to join a particular organisation. Therefore, implications for managers may be drawn as well. Following the presented results and arguments, we would recommend the development of a clear CSR communication strategy, especially in the recruitment process. Thus, integration between CSR and human resources management may be beneficial. By using CSR, an organisation could attract fresh talent, and hence gain additional advantages in terms of increased innovativeness ${ }^{34}$.

32 Ibidem.

33 Ibidem.

34 See: A. Jasińska-Biliczak, Endogeniczne uwarunkowania innowacyjności sektora matych $i$ średnich przedsiębiorstw w regionie - ujęcie teoretyczne i praktyczne, Polska Akademia Nauk, Komitet Przestrzennego Zagospodarowania Kraju, Warszawa 2017; J. Kowal, J. Mäkiö, A. Jasińska-Biliczak, Business competencies as an innovation capability of IT users in Poland and Germany. Experimental study, [in:] 2017 IEEE 15th International Conference on Industrial Informatics (INDIN), Emden 2017, pp. 905-910; P. Bębenek, Effective innovation management 
The presented research has some limitations, however, which may indicate future research opportunities. The research was designed to enable a comparison between the psychological aspects of attitudes towards CSR-based employer attractiveness of Generations $\mathrm{Y}$ and $\mathrm{Z}$. Thus, the research area was rather narrow. A broader analysis of the influence of Generation Z's attitudes towards CSR in terms of employment choices should be conducted. This could include the way they function in an organisation, such as their satisfaction and engagement level in (un)ethical organisations and their willingness to leave an unethical organisation. Secondly, a comparison not only to Generation Y but also other generations could shed more light on the influence of attitudes towards CSR concerning the functioning of organisations and help better understand the nature of attitudes towards CSR. Thirdly, the research was conducted only on Polish representatives of Generation Z. As inward migration is now beginning to play an important role in the Polish context ${ }^{35}$, further research should also cover a comparison between respondents representing various cultural backgrounds, as their values and attitudes may influence the results.

\section{References}

Amaladoss M.X., Manohar H.L., Communicating Corporate Social Responsibility - A Case of CSR Communication in Emerging Economies, "Corporate Social Responsibility and Environmental Management" 2013, no. 20, issue 2, pp. 65-80.

Aronson E., Wilson T.D., Akert R.M., Social psychology, Prentice Hall/Pearson Education, New Jersey 2002.

Austin T.L., Clark L.C., Sigmar L.S., Practical Persuasive Communication: The Evolving Attitudes of the iGeneration Student, "e-Journal of Business Education and Scholarship of Teaching" 2018, no. 12, issue 3, pp. 14-33.

Backhaus K.B., An Exploration of Corporate Recruitment Description on Monster.com, "Journal of Business Communication" 2004, no. 41, issue 2, pp. 115-136.

Backhaus K.B., Stone B.A., Heiner K., Exploring the Relationship Between Corporate Social Performance and Employer Attractiveness, "Business \& Society" 2002, no. 41, issue 3, pp. 292-318.

in a company - innovation assessment criteria, [in:] Proceedings of the 4th International Multidisciplinary Scientific Conferences SGEM2017, Social Sciences \& Arts Conference Proceedings, Bulgaria 2017, pp. 121-128; P. Bębenek, Enterprise Innovation Management - Integration of the Process, Product, Marketing and Organisation Changes, [in:] K. Malik, Ł. Dymek (eds), Effective Transfer of Knowledge from Science to Industry in the Opolskie Voivode-ship: Requirements for an Effective Cooperation, Difin, Warszawa 2015, pp. 165-175.

35 See: S. Kubiciel-Lodzińska, Zatrudnienie cudzoziemców w przedsiębiorstwach: determinanty i perspektywy (przykład województwa opolskiego), Wydawnictwo Uniwersytetu Ekonomicznego, Katowice 2016; S. Kubiciel-Lodzińska, Imigracja zarobkowa do województwa opolskiego. Skala, warunki i perspektywy, Politechnika Opolska, Opole 2012. 
Barrena-Martinez J., Lopez-Fernandez M., Marquez-Moreno C., Romero Fernandez P.M., Corporate Social Responsibility in the Process of Attracting College Graduates, "Corporate Social Responsibility and Environmental Management" 2015, no. 22, issue 6, pp. 408-423.

Basu K., Palazzo G., Corporate social responsibility: A process model of sensemaking, "Academy of Management Review" 2008, no. 33, issue 1, pp. 122-136.

Bednarska M., Grobelna A., Zmiana pokoleniowa na rynku pracy w turystyce, "Studia Oeconomica Posnaniensia" 2017, no. 5, issue 4, pp. 104-125.

Behrend T.S., Baker B.A., Thompson L.F., Effects of Pro-Environmental Recruiting Messages: The Role of Organizational Reputation, "Journal of Business and Psychology" 2009, no. 24, issue 3, pp. 341-350.

Bębenek P., Effective innovation management in a company - innovation assessment criteria, [in:] Proceedings of the 4th International Multidisciplinary Scientific Conferences SGEM2017, Social Sciences \& Arts Conference Proceedings, Bulgaria 2017, pp. 121-128.

Bębenek P., Enterprise Innovation Management - Integration of the Process, Product, Marketing and Organisation Changes, [in:] K. Malik, Ł. Dymek (eds), Effective Transfer of Knowledge from Science to Industry in the Opolskie Voivode-ship: Requirements for an Effective Cooperation, Difin, Warszawa 2015, pp. 165-175.

Cilliers E.J., The challenge of teaching generation Z, "PEOPLE: International Journal of Social Sciences" 2017, no. 3, issue 1, pp. 188-198.

Csobanka Z.E., The Z generation, "Acta Technologica Dubnicae" 2016, no. 6, issue 2, pp. 63-76.

Dolot A., Co motywuje do pracy pokolenie Z - wybrane zagadnienia - wyniki badań empirycznych, "Przedsiębiorczość i Zarządzanie" 2018, no. 19, issue 8, pp. 227-242.

Dolot A., Proces poszukiwania pracy przez młode pokolenie - wybrane zagadnienia - wyniki badań empirycznych, "Studia Ekonomiczne" 2018 , no. 359, pp. 284-299.

Dolot A., The characteristics of Generation Z, "E-mentor" 2018, no. 74, issue 2, pp. 44-50.

Evans W.R., Davis W.D., An Examination of Perceived Corporate Citizenship, Job Applicant Attraction, and CSR Work Role Definition, "Business \& Society" 2011, no. 50, issue 3, pp. 456-480.

Gajda J., Analiza wybranych aspektów oczekiwań zawodowych przedstawicieli pokoleń Y i Z, "Zarządzanie Zasobami Ludzkimi" 2019, no. 5, issue 130, pp. 93-112.

Jasińska-Biliczak A., Endogeniczne uwarunkowania innowacyjności sektora małych i średnich przedsiębiorstw w regionie - ujęcie teoretyczne i praktyczne, Polska Akademia Nauk, Komitet Przestrzennego Zagospodarowania Kraju, Warszawa 2017.

Klimkiewicz K., Oltra V., Does CSR Enhance Employer Attractiveness? The Role of Millennial Job Seekers'Attitudes, "Corporate Social Responsibility and Environmental Management" 2017, no. 24 , issue 5 , pp. 449-463.

Kowal J., Mäkiö J., Jasińska-Biliczak A., Business competencies as an innovation capability of IT users in Poland and Germany. Experimental study, [in:] 2017 IEEE 15th International Conference on Industrial Informatics (INDIN), Emden 2017, pp. 905-910.

Kubiciel-Lodzińska S., Imigracja zarobkowa do województwa opolskiego. Skala, warunki i perspektywy, Politechnika Opolska, Opole 2012.

Kubiciel-Lodzińska S., Zatrudnienie cudzoziemców w przedsiębiorstwach: determinanty i perspektywy (przykład województwa opolskiego), Wydawnictwo Uniwersytetu Ekonomicznego, Katowice 2016.

Lazányi K., Bilan Y., Generation Z On The Labour Market - Do They Trust Others Within Their Workplace?, "Polish Journal of Management Studies" 2017, no. 16, issue 1, pp. 78-93.

Maden C., Arikan E., Telci E.E., Kantur D., Linking corporate social responsibility to corporate reputation: a study on understanding behavioral consequences, [in:] Proceedings of the 8th International Strategic Management Conference, 2012, no. 58, pp. 655-664. 
Mazurek-Łopacińska K., Generacja Z - cele, wartości życiowe i wyzwania dla współczesnych przedsiębiorstw, "Konsumpcja i Rozwój” 2018, no. 160, issue 4, pp. 62-75.

Melo T., Garrido-Morgado A., Corporate Reputation: A Combination of Social Responsibility and Industry, "Corporate Social Responsibility and Environmental Management" 2012, no. 19, issue 1, pp. 11-31.

Mladkova L., Generation Z in the Literature, [in:] Proceedings of the 14th International Conference Efficiency and Responsibility in Education, Czech University of Life Sciences, Prague 2017, pp. 255-261.

Perez A., Bosque I.R. del, Corporate social responsibility and customer loyalty: exploring the role of identification, satisfaction and type of company, "Journal of Services Marketing" 2015, no. 29 , issue 1 , pp. 15-25.

Ratajczak J., Pozyskiwanie i utrzymanie w organizacji pracowników z pokolenia Z w kontekście ich oczekiwań względem pracy, "Prace Naukowe Uniwersytetu Ekonomicznego we Wrocławiu" 2018, no. 512, pp. 206-215.

Wiktorowicz J., Warwas I., Pokolenia na rynku pracy, [in:] J. Wiktorowicz, I. Warwas, M. Kuba, E. Staszewska, P. Woszczyk, A. Stankiewicz, J. Kliombka-Jarzyn (eds), Pokolenia - co się zmienia? Kompendium zarzq̨dzania multigeneracyjnego, Wolters Kluwer, Warszawa 2016, pp. 19-37.

Żarczyńska-Dobiesz A., Chomątowska B., Pokolenie "Z" na rynku pracy-wyzwania dla zarzqdzania zasobami ludzkimi, "Prace Naukowe Uniwersytetu Ekonomicznego we Wrocławiu" 2014, no. 350, pp. 405-415.

\section{Abstract}

Corporate Social Responsibility has become an important instrument in the development of an employer's branding strategy. Research shows that Generation $Y$ is highly sensitive in regards to CSR issues, and that CSR influences their perception of an employer's attractiveness. However, the question this paper aims to find an answer to is whether this would also apply to the next generation, Generation Z. For this purpose, we conducted a survey $(n=250)$ with a sample of representatives of Generation Z. The findings suggest that Generation Z perceives CSR as an important factor in their choice of employer, however not important enough to convince them to reject a job offer if the employer is not perceived as ethical and responsible.

Keywords: corporate social responsibility, employer attractiveness, employer branding, Generation Z, Millennials 